http://spilplus.journals.ac.za/

239

\title{
PERSPEKTIEWE UIT DIE TEKSWETENSKAP OP DIE VERTALING VAN EIENAME IN 'N KINDERBOEK
}

\author{
Mev. M.E. Nelson \\ P.U.vir C.H.O.
}

Die tema van hierdie konferensie, taalwetenskap vir die taalprofessies, sou 'n mens ook kon tuisbring onder die hoof van toegepaste linguistiek. In hierdie referaat word gepoog om, benewens op die toepassing van linguistiek te wys op die wyse waarop perspektiewe uit die tekswetenskap in die wydste sin, dus ook literatuurwetenskap, 'n bydrae kan lewer tot die neem van beslissings by vertaling.

Die referaat sentreer om die probleem van die vertaling van eiename in 'n kinderteks aan die hand van voorbeelde wat verkry is tydens die vertaling van die Nederlandse kinderboek Otje deur Annie M. G. Schmidt na Afrjkaans.

In verband met die vertaling van eiename word die beginsel meesal neergele (onder andere deur Newmark, 1981:70) dat 'n persoon of objek se naam nie vertaal word nje, tensy daar reeds 'n erkende vertaling bestaan. Eiename in literêre werke word meesal slegs vertaal wanneer die karakters en milieu genaturaliseer word.

Die wese van die probleem met die eiename in otje is dat sommige van hulle - in teenstelling met die meeste eiename waaraan ons gewoond is - draers is van informasie wat in die vertaling geëksplisiteer moet word. Hierdie eiename is die wat waarskynlik spesiaal gekies is om sekere assosiasies by die leser te wek.

Newmark (1981:71) noem dit name wat ' 'mean' as well as 'name". Hy stel egter as praktiese vereiste vir sulke name: The attempt must be to reproduce the connotations of the original in the $\mathrm{TL}$, but to find a name consonant with SL nomenclature, thus preserving the character's nationality' (1981:71). Hierdie vereiste is nie in ag geneem by die vertaling van otje nie, aangesien daar 'n faktor is wat die vertaling vergemaklik, naamlik die feit dat die verhaal in 'n soort onbepaalde milieu afspeel - daar word nooit die naam van 'n bekende stad genoem nie (behalwe New York, vgl. die verklaring onder 2.1). Hoewel dit in Nederlands geskryf is, en dit vir iemand wat die land ken, duidelik is dat dit daar afspeel, word die naam van die land ook nooit genoem nie. Tos en Otje is nie tipies Nederlandse karakters nie, allermins in hul leefwyse. Die karakters se 
http://spilplus.journals.ac.za/

nasionaliteit staan dus nie voorop nie, die 'betekenis' van die name wel. Daarom is 'n vertaling daarvan noodsaaklik. Newmark (1981:71) waarsku dat bogenoemde soort behandeling van eiename in vertaling nie gedoen kan word met baie bekende werke soos die van Shakespeare en Dickens nie, wel in gevalle where the work is virtually unknown in the TL culture, and where the translator is convinced that the connotations of the proper name is at least as important as the nationality.' Dit is die vertaler se oordeel dat hierdie laaste voorwaarde op Otje van toepassing gemaak kan word.

Ten einde die bespreking te kan volg, is dit wenslik dat die verhaal van Otje hier baje kortliks weergegee word: Tos, 'n kok, en sy dogtertjie, Otje, woon in Hotel De Koperwiek waar Tos vir Meneer Pardoes werk. Omdat hy nie 'papiere' het nie, word Tos swak betaal en kan enige tyd ontslaan word, wat telkens gebeur omdat hy boonop verskriklike woedebuie kry. Hy besluit na die tweede ontslag deur Meneer Pardoes om saam met Otje rond te trek in hulle stasiewaentjie. Albei van hulle kommunikeer ook met diere - die hond en kat van die hotel, die voëls in die tuin, en 'n familie muise op die solder. Twee van die muise, Lodewijk en Suzie, trek saam met hulie, want hulle is op soek na die land Musopia, die land sonder katte en valle.

Soos te verwagte wedervaar Tos en Otje heelwat in hulle omswerwinge, maar telkens duik daar wees probleme op omdat hulje nie die regte 'papiere' het nie. Uiteindelik aanvaas Tos werk vir 'n maand by Admiraal Strafport op sy skip en laat vir Otje tuis by sy twee tantes. Wanneer Tos as gevolg van'n storm nie op die afgesproke tyd terugkom nie, en die tantes die muise uit die huis sit, terwyl hulle Otje in 'n kinderhuis wil plaas, loop sy weg. Tos kom terug, vind haar nie by'die tantes nie, en word weer gevra vir sy papiere deur die polisie. Sy woedebui is dan so erg dat hy weggeneem word na ' $n$ hersteloord, waaruit hy bevry word deur Otje met die hulp van die voëls wat hulle dwarsdeur die verhaal gevolg en gehelp het, en Meneer Pypetoon. Die voëls het vir hulle van orals af papiere aangedra, onder andere ook die oorkonde waarvolgens die plekkie Kokkelburg stadsregte verkry het. Die besit van hierdie papier stel Otje in staat om vir haar pa wettige papiere in die hande te kry, en met die hulp van Meneer Pypetoon kry hy ook 'n lening vir die koop van Hotel De Koperwiek, waar die verhaal dan op 'n gelukkige noot eindig.

\section{ONTLEDING VAN EIENAME IN OTJE}

Vir die doeleindes van bespreking kan die eiename in die verhaal soos volg in kategorieë verdeel word: 
http://spilplus.journals.ac.za/

241

\section{Plekname}

\section{Karaktername}

\subsection{Plekname}

'n Volledige lys van plekname uit Otje word in Lys A aan die einde van die teks gegee. Dit blyk uit die ANWB se Reisboek voor Nederland (1965) dat elke enkele pleknaam fiktief is. Die skryfster het hulle waarskynlik elkeen geskep met die docl om 'n spesifieke assosiasie op te rocp, al is dit soms ook ' $n$ assosiasie van onheduidendheid en doodgewoonheid. Die plekname steun almal op 'n bekende agtervoegsel/tweede deel wat die leser in staat stel om dit dadelik te plaas as 'n sekere tipe plek. Daarom kan 'n mens in elke geval 'n assosiasie-voorspelling maak: Hollebrock, Kokkelburg, Kokkelse plassen, Weldorp, Koordwijk, Garzelen, Rusthuis Vredelief. Die verpligting wat nou op die vertaler rus, is om 'n ekwivalente assosiasie met die vertaling op te roep. In enkele gevalle kan die agtervoegsel/tweede deel van die naam behou word, aangesien dit in Afrikaans dieselfde tipe assosiasie sal oproep.

Hierop kry ons die volgende interessante perspektief uit die naamkunde: Soos Nicolaisen (1978:41-47) aangetoon het, het plekname dikwels aanvanklik denotatiewe betekenis wat met die tyd verlore gaan (soms omdat die oorspronklike naamgewers van 'n ander land gekom het). Later het dit dan eintlik meer net konnotatiewe betekenis (assosiasie), hoewel daar deur die vcelvuldige voorkoms van sekere tipes name ook by die bevolking wat die oorspronklike naam nie 'verstaan' nie, 'n begrip ontwikkel van die soort plek wat so 'n soort naam sal dra. Met ander woorde in 'n sin het die naam tog ook denotatiewe betekenis. Hierdie feit het byvoorbeeld betrekking op die agtervoegsel '-burg' in Afrikaans, waar min mense nog dink aan die oorspronklike betekenis van 'vesting'. Almal verstaan egter dadelik wat bedoel word as dit agteraan 'n naam gevoeg word. Vanweë die verwantskap tussen Nederlands en Afrikaans hoef dit nic vertaal te word nie.

Aangesien by die vertaling van die plekname nie soveel gesteun is op perspektiewe uit die tekswetenskappe nie, maar meer op 'landeskunde' word hier slegs aan twee ander plekname kortliks aandag gegee.

Die naam Musopia verdien afsonderlike bespreking: Dit het 'n klankassosiasie (vir volwassenes) met Utopia waarop dit ongetwyfeld 'n parodie is, en met die Latynse mus vir muis. Dit het waarskynlik vir die jonger Nederlandse kind ewemin van bogenoemde 
http://spilplus.journals.ac.za/

242

twee assosiasies as vir die Afrikaanse kind van dieselfde ouderdom. Bowendien verduidelik die konteks - 'n land sonder katte en valle - ook die idee voldoende vir die kinderleser om dit te begryp. Om dié rede word dit behou in die vertaling.

Die sterk parodiese karakter van hierdie naam verhoog die voorspelbaarheid daarvan. Alle lesers (groot en klein) weet dat dit nie kan bestaan nie, en dus ook - terwyl die muise vir Tos en Otje volg in hul omswerwing in 'n soort skaduweeverhaal waarin hulle telkens ontnugter word - dat dit nooit bereik kan word nie.

New York is die enigste pleknaarn in die verhaal wat nie fiktief is nie. Dit word in die verhaal ingebring on deel te wees van die assosiasies rondom mevrouw Bontebaai, 'n effek wat slegs bereik kon word met die naam van 'n groot en bekende stad. Haffer (1984:23) beskou hierdie soort eienaam as 'n sosiokulturele 'afkorting'. In hierdie geval vorm dit deel van die assosiasies rondom 'n ander eienaam.

\subsection{Karaktername}

Hieronder word name van karakters (mense en diere in hierdie verhaal) bespreek.

\subsubsection{Bestaande eiename}

Soos die plekname wil die name van karakters iets oordra aan die leser. Wanneer dit dan blyk dat sommige name heeltemal 'gewoon' of 'neutraal' is, moet ons in gedagte hou dat ook hulle iets kommunikeer. Hulle gewoonheid vorm 'n kontras, 'n soort klankbord of agtergrond vir die ander meer buitengewone karakters.

Op die uitsondering van die vier hoofkarakters na lyk dit asof hierdie bestaande name slegs gebruik word vir die karakters wat onbelangrik moet wees, of net tipes is van gewone alledaagse karakters.

'n Hele aantal van hierdie name is in die vertaling net so behou, in enkele gevalle in 'n effense verafrikaanste vorm wat in hakies aangegee word. Die bestaande eiename word volledig aangegee onder Lys $\mathbf{B}$.

Die vier hoofkarakters is:

Tos

Hy is nie 'n onbelangrike karakter nie, aangesien hy die tweede boofkarakter naas Otje is. Sy baie doodgewone naam se niks van besondere persoonlikheidseienskappe nie. 
http://spilplus.journals.ac.za/

243

Dit mag so gekies wees omdat hy nie geag word nie. Aan die einde van die verhaal lees ons van hom: "...terwyl Tos aan de hoofdtafel zat naast de burgemeester. Hij was eregast. Niet meer de schichtige vervolgde vluchteling, maar een mens zoals alle anderen, een gast op het feest met een sigaar en een glas wijn."

Sy naam is ook die gewone Nederlandse afkorting vir Thomas. Dit lyk onwaarskynlik dat dit as 'n Bybelse verwysing opgeneem moet word, aangesien die hele res van die boek gekenmerk word deur'n totale afwesigheid van dergelike verwysings. Ons het dus hier te make met 'n karakter rondom wie die assosiasies deur die skryfster geleidelik opgebou is in die loop van die verhaal, en niks of baie min ontleen word aan die naam van die karakter self. As ekwivalent word die Afrikaanse verkorte vorm Tom in die vertaling aangebied.

\section{Otje}

$D i t$ is nie ' $n$ algemene naam in Nederlands nie. Die seunsnaam $O t$ as afkorting vir Otto is wel bekend. Dit kan moontlik 'n aanduiding wees daarvan dat sy ' $n$ rabbedoe is, ' $n$ bjetjie seunsagtig. Geen bewys kon gevind word dat otje ooit in Nederlands gebruik word vir 'n vuil of slordige kind soos otjie in Afrikaans nie. Daarom word Ottie liewer as vertaling aangebied.

\section{Lodewijk en Suzie}

Hulle is die muise, die twee hoofkarakters van die skaduweeverhaal. As ons kyk na die vier hoofkarakters van hierdie verhaal, vind ons dat sulle al vier gewone, bestaande name het, en dat die assosiasies rondom hulle dus volledig bestaan uit die karakteropbou wat met die verloop van die verhaal plaasvind. Dus verval die nodigheid om die naam te 'yerduidelik' deur dit in die vertaling te vervang met iets anders. Gevolglik word hierdie name ook behou in die vertaling met die nodige verafrikaanste spelling.

\subsubsection{Eiename geskep met 'n spesifieke doel}

Daar bly egter nog 'n aantal karaktername oor in hierdie verhaal wat opval ondat hulle nie bestaande name is nie, maar waarsicynlik deur die skryfster bedink is om 'n sekere effek te bereik. Hulle is vervat in die tabel in Lys D. 'n Poging om hierdie name te ontleed met behulp van komponentanalise wat berus op referensiële betekenis (Nida, 1975:30), het dit gou duidelik laat word dat hulle trefkrag eerder berus op assosiasie. 
http://spilplus.journals.ac.za/

Onder hierdie kategorie van eiename is daas die subkategorie van klanknabootsende name. Teoreties sou hulle net so moet bly staan, wat tog nie in alle gevalle so gedoen is nie, aangesien ook onomatopee in 'n mate bepaal word deur konvensie wat berus op die manier waarop die oor van elke taal-groep ingestel is. (Engelse honde maak tradisioneel bow-wow, Afrikaanses woef-woef). Hierdie name is vervat in Lys $\mathrm{C}$ aan die einde van die teks.

Die ontleding van assosiasie kom einttik neer op 'n voorspelling van die assosiasies wat die naam sal hê vir die leser, eerstens vir die eerste leser, dié van die bronteks. Daarna volg dan die besluit oor hoe om hierdie assosiasies te ewenaar in die vertaling sodat dit 'n min of meer ekwivalente assosiasie sal hê vir die leser van die doelteks (vertaling). Op die manier kan die graad van ekwivalensie wat met die vertaling bereik is, geëvalueer word.

Daar moet in gedagte gehou word dat ' $n$ mens normaalweg glad nie gemoeid is met die betekenis van 'n naam nie. Maar Annie Schmidt het (soos ander skrywers waarna verwys sal word) deur die gee van sulke name 'n soort verstandhouding geskep tussen skrywer/teks en leser, soveel so dat 'n mens dan begin wonder oor die 'betekenis' as sy 'n gewone, bestaande naam gebruik.

Die vertaalprobleem by hierdie name word dus gereduseer tot die interpretasie, voorspelling en herskepping van die assosiasies wat hulle oproep.

\section{PERSPEKTIEWE OP ASSOSIASIE}

Assosiasie is iets wat veral psigoloë interesseer, maar aangesien psigologie nie as 'n tekswetenskap bestempel kan word nie, word die psigologiese perspektief nie hier behandel nie. Daar word volstaan deur te konstateer dat met psigologiese ondersoek bewys is dat daar so iets bestaan soos 'n gemiddelde voorspelbare assosiasie wat deur algemene woorde opgeroep word, spesifiek ook by kinders. Verder verskaf die psigologie nuttige klassifikasie van die tipes assosiasies (veral in die werk van Moran). Vir die doeleindes van die vertaling van eierame in die verhaal het die tipes predikatiewe en funksionele assosiasies veral nuttig geblyk. Met ander woorde met die besondere eiename was dit blykbaar die skryfster se bedoeling om die kinderleser te laat dink : hoe is hierdie karakter? of: wat doen hy/sy? Die gebruik van sulke name behels dus 'n soort verskuilde opdrag aan die kinderlesers wat hulle gedagtes rig. 
http://spilplus.journals.ac.za/

245

By die verkenning van literatuur oor assosiasie blyk dit dat daar vanuit verskillende studievelde perspektiewe verkry kan word op name met voorbedagte assosiasies. Die name word bekyk vanuit die perspektief van:

* linguistiek

* literère konvensie

- narratologie

- teorie van resepsie-estetika

- naamkunde

\subsection{Linguistiese perspektief}

Clark (1970:275) gee 'n linguistiese verklaring van hoe assosiasieresponse werk. Hy probeer 'n ontleding gee (1970:275-284) van die linguistiese reëls wat toegepas word by die gee van assosiasieresponse. Hy volg die tradisionele onderskeid tussen paradigmatiese en sintagmatiese response (vgl. De Saussure (1966:82-23) oor sintagmatiese en assosiatiewe verhoudings). Aangesien hy dit stel dat paradigmatiese response (in assosiasietoetse) baie meer voorkom by volwassenes, terwyl ons hier met 'n kinderboek te make het, en aangesien dit blyk uit Lys $\mathrm{D}$ dat die meeste assosiasies wat ter sprake is by hierdie vertaling predikatief of funksioneel, dus sintagmaties van aard is, word slegs die sintagmatiese reëls hier bespreek. Hy behandel twee reëls wat 'n skynbare verklaring bied vir die meeste sintagmatiese assosiasieresponse:

\section{Die reél van die realisasie van die seleksiekenmerk}

Die lys van (semantiese) kenmerke vir 'n woord bevat dikwels seleksiekenmerke wat deels die betekenis karakteriseer van die potensiële konteks van die woord. So het die adjektief jonk seleksiebeperkings ten opsigte van die s.nwe wat dit kan bepaal. Baie van die response op jong/jonk is bloot spesifieke verwerklikings van hierdie eienskap, byvoorbeeld seun, kind, meisie, man. Om hierdie respons te gee, het die respondent die gedeeltelike kenmerkelys ('partial feature list') geneem [+s.nw., + lewend] en dit aangevul met ander kenmerke, en die resultaat gegee. Die bygevoegde kenmerke was dikwels ander kenmerke van jong, aangesien party response woorde was met die kenmerk [volwasse] (seun, meisie, kind). Die reël wat hierdie response verklaar, kan soos volg geformuleer word:

Neem die kenmerke wat gespesifiseer word deur 'n seleksiekenmerk, voeg soveel kenmerke by as wat nodig is vir 'n oppervlakte-realisasie; verder, 
http://spilplus.journals.ac.za/

beperk jouseif tot die belangrike deel van die seleksiekenmerk, dié deel wat 'n ieksikale woord spesifiseer.

Die name in die tabel in Lys D waarvan die assosiasies as predikatief geklassifiseer is, val dus saam met'hierdie reël van Clark. In die geval van mevrouw Bontebaai byvoorbeeld, is die voor die hand liggende assosiasie van die naam dat sy ryk en deftig is, 'n indruk wat inderdaad versterk word deur die verdere verloop van die verhaa'.

Die implikasie vir die vertalet is dus die verpligting om 'n naam te skep waarvan die assosiasie op dieselfde manier sal werk. Hier is gekies vir die vertaling Mevrou Pelsekleed.

Wat wel opvallend is, is dat hierdie realisering van seleksiekenmerke (predikatiewe assosiasie) in al hierdie gevalle volg op selfstandige naamwoorde, terwyl Clarke verwys na Chomsky, (1965) wat selfstandige naamwoorde sien as sonder enige seleksiekenmerke, hoewel werkwoorde, adjektiewe en ander kategorieë dit wel het. Dit impliseer dat selistandige naamwoorde taamlik min sintagmatiese response behoort uit te lok. As bewys hiervoor haal hy die werk aan van Deese (1962) waar selfstandige namwoorde uit 'n groot aantal stimuli slegs in $21 \%$ van die gevalle sintagmatiese response uitgelok het, teenoor die $48 \%$ by werkwoorde, en $50 \%$ by adjektiewe.

Hierdie skynbare teenstrydigheid kan myns insiens verklaar word uit die opset waarmee die name in die verhaal gegee word, naamlik om 'n sekere karakter te tipeer (soos eerder al genoem is). Die kind se vorming van assosiasies sou dus in elke geval 'n antwoord wees op die vraag: hoe is .... ? eerder as: wat is ...? Laasgenoemde sou ' $n$ paradigmatiese assosiasie opgeroep het.

\section{Die reêl van die voltooiing van idiomatlese uitdrukkings}

Response op stimuli vorm dikwels saam met die stimulus 'n algemene idiomatiese uitdrukking, byvoorbeeld wit - huis; maas - kaas.

Die reël wat ten grondslag lê van so 'n respons stel Clark (1970:282) by gebrek aan beter semantiese spesifikasies vir idiomatiese uitdrukkings soos volg:

Vind ' $n$ idiomatiese uitdrukking waarvan die stimulus 'n deel vorm, en verskaf die volgende belangrike woord. 
http://spilplus.journals.ac.za/

247

Wat Clark hier beskryf, is in wese dieselfde wat Van der Made-van Bekkum (as toevoeging tot die kategorieẽ van Moran) leksikale voltooiings noem.

Hierdie tweede reël van Clark vir sintagmatiese assosiasies, kan verder ook van toepassing gemaak word op dié name uit die tabel in Lys D waarvan die assosiasies as funksioneel aangegee is (dit wil sê die leser se assosiasie is 'n antwoord op die vraag: wat doen hierdie karakter?) Die uitdaging vir die vertaler is om 'n naam te skep in die doeltaal wat dieselfde soort assosiasie sal oproep, byvoorbeeld Juffrouw Ochtendster (kom vroeg uit, word vroeg gesien) wat vertaal is met Juffrou Môrester of Marjus Mengel (gooi dinge bymekaar, flans stories saam). In laasgenoemde geval is die naam so behou in die vertaling.

Dit is wel belangrik om daarop te let dat die meeste van die name reeds twee komponente bevat (terwyl Clark praat van een komponent wat 'n ander suggereer) maar dat hierdie twee komponente dan wel 'n derde suggereer:

Meneer (sal) Self (kom)

Juffrou Môrester (kom vroeg uit)

Meneer (laat ander na sy) Pype/dans

Marius Mengel (flans dinge saam)

\subsection{Die perspektief van literêre konvensie}

Mieke Bal (1980:91) meen in haar inleidende werk oor narratologie dat elke karakter min of meer voorspelbaar is, en dat elke volgende mededeling oor die karakter dan die moontlikhede van wat gaan volg, verder beperk. So noem sy byvoorbeeld geslag, beroep, die persoon van die verteller en dan ook die beperkings wat deur 'n naam opgelè word. Daarin lê, behalwe die geslag, dikwels ook sosiale status en geografiese herkoms opgesluit. Name kan ook gemotiveer wees, dit wil sê betrekking hê op eienskappe van die karakter. Sy haal voorbeelde aan uit die werk van Agatha Christie. Wat hier beklemtoon moet word, is dat hoewel die gebruik van fiktiewe eiename opval in hierdie boek, dit hoegenaamd nie uniek is in die letterkunde nie. Dit is 'n konvensie wat by 'n hele aantal bekende skrywers aangetref word. Ons verwys hier vlugtig na Shakespeare (met name soos Malvolio, Benvolio), Congreve (vergelyk die volgende name, almal uit The Way of the World: Sir Willfull, Lady Wishfort, Petulant, Mirabell, Fainall), Dickens (met sy Scrooge, Oliver Twist, Richard Swiveler), Sheridan (Lady Sneerwell, Mrs. Candour uit The School for Scandal) en selfs Etienne le Roux (vgl. die 
http://spilplus.journals.ac.za/

keuse van die naam Salome vir die vroulike hoofkarakter in Sewe dae by die Silbersteins). By Dickens was dit 'n integrale deel van sy verteltegniek. Soos die res van sy beskrywing, was dit bedoel on sekere dinge aan die leser te kommunikeer en om meteens 'n baie spesifieke impak op die leser te maak (vgl. Sucksmith, 1970:15).

Smith (1966:497) sê: ' Fiction, especially the more vulgarly humorous, tends definitely to employ names evolved from words which serve to suggest the character portrayed.' By skrywers wat van hierdie konvensie gebruik mak, vind 'n mens gewoonlik dat dit die karakters is wat betreklik simplisties voorgestel word wat sulke name het, veral in satiriese werke. Dit klop ook met die bevinding dat die name in Otje wat so is, min of meer eenduidig is, dus nie 'n hele aantal eienskappe benoem nie. Die implikasie vir die vertaling is dus dat die name van sulke karakters ook in die doelteks hierdie eienskappe moet benoem. Die karakters wat minder van karikature is en meer hoofrolle speel, het gewoonlik nie sulke name nie. Dit is reeds aangetoon met die bespreking van die name van Tos, Otje, Lodewijk en Suzie. Dit geld ook (in die meeste gevalle) vir sulke karakters in Dickens.

\subsection{Narratologiese perspektief}

Die onderafdeling van literatuurwetenskap wat bekend is as narratologie, bied uiters interessante perspektiewe op die vertaling van die tipe eiename onder bespreking. Wanneer ons die verhaal ontleed volgens die aktansiële model van Greimas, kom daar 'n aantal baie interessante aspekte na vore: Volgens Greimas is daar 'n basiese gemeenskaplike 'grammatika' wat aan die lig kom by strukturele analise van 'n verhaal, wat net so basies onderliggend is aan verskilende verhale as wat Chomsky se 'competence' onderliggend is aan enige taaluiting of 'performance' (Hawkes, 1977:89). Op grond van hierdie onderliggende permanente struktuur wat in dieselfde verhouding tot verbale staan as langue tot parole, ontwikkel Greimas sy model van aktante, dit is vaste rolle waarin akteurs sekere funksies vernal (Du Plooy, 1984:172). As strukturalis is Greimas geinteresseerd in die verhoudings tussen elemente, en dus kyk hy na gebeure en akteurs vanuit die verhoudings van die akteurs tot die gebeurtenisse wat hulle veroorsaak of ondergaan. Hy veronderstel doelgerigtheid by die menslike denke en handeling, en daarom is sy model daarop gerig om die verhouding tot die nagestreefde doel weer te gee.

$\mathrm{Na}$ aanleiding van die verhouding warin die akteurs staan tot die nagestreefde doel, maak Greimas 'n klassifikasle van akteurs, en elke klas akteurs noem hy 'n aktant. Die suewe (inspanning om die doel te bereik) beskou hy as die kern van die geskiedenis. 
http://spilplus.journals.ac.za/

249

Die verhouding waarin die aktant (klas van akteurs) staan tot die strewe, noem Greimas die funksie (Brink, 1987:23). Behalwe dat hy by elke verhaal 'n fundamentele struktuur veronderstel, beweer hy dat hierdie struktuur analoog sal wees aan die semantiese struktuur van die sin. In hierdie indeling werk Greimas op die basis van die werk van Propp (1968, aangehaal deur Rimmon-Kenan, 1983:20-22, en deur Du Plooy, 1984:174) wat hy verder reduseer. Hier word slegs verwys na die model van Greimas self sonder verdere aanduiding van die werk van Propp. Greimas onderskei drie pare binêre teenstellings waarin alle aktante pas en wat alle funksionele akteurs van enige verhaal insluit, nl.:

1 Subjek versus objek. Die subjek is die held, die objek is die persoon of saak wat die held graag wil verwerf, dit wil sê sy doel. Die verhouding tussen die twee aktante stem ooreen met die verhouding tussen die onderwerp en die voorwerp in die sin.

2 Begunstiger en begunstigde. 'n Subjek kan dikwels nie sy doel bereik nie, en word daartoe in staat gestel of daarvan weerhou deur ander magte wat 'n rol speel in die verhaal. Die aktant wat die strewe van die subjek aanhelp of begunstig, is die begunstiger, en die ontvanger van die objek is die begunstigde. Dikwels is die subjek en die begunstigde dieselfde karakter.

3 Helper en teenstander. 'n Verhaal word gekompliseer en uitgebrei deur die aktante van helper en teenstander - die subjek kry hulp of kry met teenstand te doen. Die aktante van helper en teenstander staan nie in 'n direkte verhouding tot die objek nie, maar tot die funksie wat die subjek en objek verbind. Die helper en teenstander is aktante wat slegs ' $n$ sekondere rol speel, omdat hulle slegs by geleentheid die verhaal beïnvloed, wat in dieselfde verhouding staan tot die hoofaktante as byvoeglike naamwoorde tot selfstandige naamwoorde of bywoorde tot werkwoorde in die sin.

In die verhaal van Tos en Otje se omswerwinge, is die papiere beslis 'n aktant, en wel as objek, aangesien dit die doel is waarna die hele tyd gestrewe word. (Dit het die implikasie vir die vertaling dat dit foutief sou wees om dit soms as dokumente te vertaal. Dit val ook op dat daar twee ondergeskikte intriges in die verhaal is waarin papiere ' $n$ groot rol speel. In albei gevalle word dié papiere uiteindelik deel van die verhaal van Tos se papiere.) Die teëhanger van hierdie objek in die verhaal van die muise is die land Musopia. 
http://spilplus.journals.ac.za/

Wanneer ons kyk na die elf name wat in die tabel in Lys D vervat is, blyk dit dat elkeen van hierdie karakters 'n belangrike rol speel in een of meer episodes voordat die verhaal weer verder beweeg. Hulle kan almal volgens die model van Greimas ingedeel word as of helpers of teëstanders. Teëstanders is dan: meneer Pardoes, mevrouw Bontebaai, meneer Zelf, Zuster Snijbiet en, wanneer dit fyn ontleed word, ook Admiraal Strafport. Dus kan ons met veiligheid beweer dat die skryfster vir die teëstanders in hierdie verhaal almal spottende of onaangenaam-klinkende name gekies het.

Marius Mengel, Heppie die hond, Juffrouw Twiddel, Juffrouw Ochtendster en meneer Pijpetoon (alias Dr H. van Zwavel) moet gereken word tot helpers. Hierdie indeling word versterk deur die feit dat hulle almal (behalwe Juffrouw Ochtendster) weer in die laaste hoofstuk verskyn as besoekers by Tos se hotel.

As ons die model van Greimas verder toepas, kan ons die voëls as begunstigers deur die hele verhaal sien: "'t Is allemaal in orde gekomen, dank zij de burgemeester van Kokkelburg,' zei hij. 'Nee,' zei Otje. 'Dank zij de vogels.' ")

Hierby kom ook Herman, die hond, wat aanvanklik na 'n teëstander lyk, en tog telkens in die loop van die verhaal weer Tos en Otje se saak bevorder.

Hierdie ontleding op die model van Greinas bring ons tot die volgende baie interessante gevolgtrekkings wat ook implikasies het vir die vertaling:

1 Die hoofkarakters (subjekte) het gewone, bestaande name (Tos, Otje, Lodewyijk en Suzie).

Ook die begunstigers wat deurgaans tot hulp van die subjek(te) kom, het gewone bestaande name, behalwe die voëls wie se name klanknabootsend is. Die helpers en teëstanders wat almal net vir een of twee episodes optree, het fiktiewe name wat spottende, onaangename of (in die geval van helpers) aangename assosiasies het. Daar is gepoog om dit in die vertaling te ewenaar.

\subsection{Perspektief verkry uit die teorie van resepsie-estetika}

Brink (1987:71) sê die volgende oor die eiename van karakters in literêre werke, 'die eerste verskyning van 'n nie-historiese eienaam skep 'n soort semantiese 'spasie' of 'oopte' in die teks' : dit is in der waarheid 'n 'leë teken', 'n betekenaar wat nog geen betekende gevind het nie, maar wat 'n oopte gereed hou om gevul te word' Hierdie gedagte het sy oorsprong by Iser. Hy sluit weer aan by Imgarden se idee dat die leser 
http://spilplus.journals.ac.za/

van 'n teks self die 'skematiese in' aes' wat die teks bied, moet voltooi. Iser (1980:113) skep hiervoor die term 'gapings' ('bianks').

Die kwessje van assosiasie kan ook aangeknoop word by Jauss (1982:589 e.v.) se begrip van verwagtingshorison by die lees van 'n literêre werk, en die estetiese afstand, dit wil sê die verskil wat daar is tussen die leser se verwagting en die aanpassing wat hy moet maak by wat hy in die teks aantref. As ons kyk na die eiename in die tabel in Lys D by hierdie hoofstuk, is dit duidelik dat die estetiese afstand veral hier ter sake is by hierdie oorspronklike geskepte name en die assosiasies wat hulle oproep en ook dat dit wisselend is. Sommige is baie voor die hand liggend (meneer Pardoes: Meneer Kaplaks (Die woord 'pardoes' word later gewoon in 'n sin gebruik wat hierdie vertaling gesuggereer het), Marjus Mengel; Juffrouw Ochtendster : Juffrou Môrester). Ander verg 'n bietjie meer 'dinkwerk' van die leser (mevrouw Bontebaai : Mev. Pelsekleed; Admiraal Strafport; meneer Pijpetoon : Meneer Pypedans). Verder word die inspanning aan die leser se kant aangehelp deur die versterking van die assosjasies met wat nog meer in die teks meegedeel word oor die betrokke karakter, sodat met veiligheid gesê kan word dat nie een van die eiename in Otje so teen die verwagtingshorison ingaan dat dit onbegryplik word vir die leser nie. In die vertaling is ook daarna gestreef om dit so te hou, met inagneming van die doeltaallesers se verwysingsraamwerk. Die begrip 'verwagtingshorison' is dus vir die vertaler 'n waardevolle riglyn.

Bal wys ook daarop (1980:92) dat aan die verwagtings wat geskep word, voldoen kan word, of hulle kan deurbreek word. In die verhaal van Otje is geen enkele voorbeeld van laasgenoende gevind nie, behalwe dat die karakters van Tos en Otje nie so eenvoudig blyk om te voorspel nie. Albei doen ook dinge wat 'n mens by die eerste kennismaking nie sou verwag het nie. Die hoë mate van voorspelbaarheid hou waarskynlik verband daarnee dat dit 'n kinderverhaal is, en dat die voorspelbaarheid van die karakter ten nouste saamhang met die verwysingsraamwerk van die leser.

\subsection{Naamkundige perspektief}

Uit die naamkunde-studie van Kruger (1988) wat 'n ontleding gemaak het van 'n aantal name in Sepulana ('n Noord-Sotho- dialek) word 'n interessante perspektief verkry. Kruger gee ' $n$ beskrywing en ontleding van al die verskillende name wat iemand van hierdie stam gedurende sy leeftyd gegee word (nege altesame). Sy kom tot die gevolgtrekking dat die naamgewer put uit sy kennis (of intuïtiewe aanvoeling) van die 
http://spilplus.journals.ac.za/

werklikheid wanneer naamgewing plaasvind. Die werklikheid dien dus as 'n stimulus vir naamgewing. Die naam het as bron een of meer aspekte van die totale werklikheid.

Hierdie bevinding kan myns insiens ook van toepassing gemaak word op fiksie (by name die tipe fiksie wat ons in otje het) waar ons dan te doen het met die 'verhaalwerklikheid' (eie term) wat deur die skrywer daargestel word en waarvan ook net sommige aspekte geselekteer word om te aksentueer. Uiteraard het dit implikasies vir die vertaler van hierdie verhaal.

Kruger (1988:60) lê breedvoerig uit dat persoonsname in die Afrikatale deel vorm van 'n kommunikatiewe handeling. Dit is belangrik om die name na die verskuilde semantiese waarde daarvan te beoordeel, soos bedoel deur die naamgewer (Kruger, 1988:170). In die geval van byname is die semantiese inhoud meer eksplisiet. Die semantiese inhoud van die bynaam (in Sepulana) het betrekking op die naamdraer self en sy ervaring van dje wêreld (Kruger, 1988:171).

Daar moet in gedagte gehou word hoe groot die verskil is tussen die kultur van die Afrikatale en die westerse kultuur. Nogtans kom 'n duidelike parallel na vore tussen die bedoeling met die fiktiewe eiename in Otje (Lys $D$ ) en die gee van byname deur die sprekers van Afrikatale. In albei gevalle selckteer die naam 'n eienskap of handeling en lig dit uit. Ook hierdie perspektief het die implikasie vir vertaling dat hierdie ejenskappe geanaliseer en in die doeltaal geëksplisiteer moet word.

Soos by die Afrikatale lê in Bybelname (die eerste wat aan 'n kind gegee is, dus nie byname nie) opgesluit wat die naamgewer/ouer beweeg of angespreek het by die geboorte (vgl. Gen 30:11) (Noth, 1980:5). Boonop is die gee van byname na aanleiding van gebeurtenisse of karaktereienskappe - wat inhou dat die oorspronklike naam nie altyd gehandhaaf word nie - 'n praktyk wat ook uit die Bybel aan ons bekend is, vergelyk Abram > Abraham (Gen. 17:5), Jakob > Israel (Gen 32:28).

Noth, wat 'n studie gemaak het van Semitiese en Israelitiese naamgewing, waarsku dat in dié studieveld moeilik 'n eenduidige uitleg aan 'n enkele naam gegee kan word, en dat dit eers met sekerheid verklaar kan word wanneer dit qua vorm en inhoud met ander name verbind word. Hoewel dit baie verskil, moet in die onderhawige studie van eiename ook daarop gelet word dat daar slegs tot die tipe gevolgtrekkings gekom kan word wat hier aangebied word omdat elke fiktiewe naan gesteun word deur meer sulke name, en omdat die konteks waarin die naam gebruik word, dit verder 'verduidelik'. Noth (1980:12) verdeel op grammatikale gronde Semitiese name in twee hoofgroepe: 


\section{http://spilplus.journals.ac.za/}

253

name wat direk betrekking het op die draer en as selfstandige naamwoorde behandel kan word, en name wat op sigself 'n sin vorm. Dit kom voor of hier weer eens ' $n$ indeling gegee word wat korrespondeer met die predikatiewe en funksionele assosiasies. Dit is egter belangrik dat die name in Otje meer ellipties van aard is, en die Israelitiese persoonsname baie meer eksplisiet.

Gemser (1924:3) wys op die feit dat by die ou volke meesal in die naam iets weergegee is van die persoon, en die naam gelyk geag is aan die persoon. Met huiwering sou ' $n$ mens ook die volgende woorde van Gemser (1924:2) van toepassing kon maak op die skrywer wat 'n karakter skep, hom/haar 'n besondere naam gee, en dan verder laat optree in die verhaal: 'Scheppen, benoemen en het lot bepalen zijn drie momenten van dezelfde daad, het is dezelfde daad uit verschillend oogpunt bezien.'

'n Mens sou redelikerwys kon aanvaar dat die kennis van sulke Bybelse naamgewing en naamsveranderinge deel uitmaak van die meeste Afrikaanssprekende kinders se verwagtingshorison en dat dit hulle des te meer ontvanklik maak vir dié tipe name in Otje, en die weergawe daarvan in die vertaling.

\section{SAMEVATTING}

Hierdie insigte uit die tekswetenskap in verband met eiename en hul assosiasies het, soos telkens angetoon is, bepaalde implikasies vir die strategie wat 'n vertaler met sulke name behoort te volg. Hierdie verrtaalstrategieë kan soos volg saamgevat word:

- Name wat ooglopend bedoel is om sekere assosiasies te wek, moet ontleed word met die oog daarop om vas te stel wat die essensie is van die assosiasie wat gekommunikeer word. Sekere linguistiese en psigologiese perspektiewe kan van nut wees om die soort assosiasie te bepaal.

- Nuwe name wat 'n soortgelyke assosiasie by lede van die doeltaalkultuur sal wek, moet gekonstrueer word.

* Twyfel oor die belangrikheid van 'n naam kan verhelder word deur 'n narratologiese ontleding van die rol van die karakter wat die naam dra. 
http://spilplus.journals.ac.za/

- Name wat as byname geklassifiseer kan word vanuit 'n naamkundige perspektief of vanuit die perspektief van literêre konvensie, moet in die doelteks só gekonstrueer word dat hulle dieselfde eienskappe uitlig as die name in die bronteks. SLOT

Hiermee is duidelik aangetoon dat linguistiese, naamkundige en verskillende literatuurteoretiese insigte baie sinvol toegepas kan word in die vertaalpraktyk.

\section{LYSTE VAN NAME UIT OTJE}

\section{LYS A : PLEKNAME}

Hotel De Kopenwiek : Die Koper Lyster Hotel

De Kroon : Die Kroon

De Stevige Pot : Die Stewige Pot

Garzelen : Garsalia

Hollebroek : Holspruit

Hotel Do-Do : Hotel Do-Do

Klaverstraat : Klawerstraat

Kokkelburg : Kokkelburg

Kokkelse plas : Kokkelse meer

Koordwijk : Koordwyk

Musopia : Musopia

Rusthuis Vredelief : Hersteloord Vredelief

Weldorp : Weldorp

\section{LYS B : BESTAANDE EIENAME}

(Slegs veranderings word aangedui.)
Annemarie
Arie
Bessie
Betsie
Dirk
Dirk-Jan 
http://spilplus.journals.ac.za/

255

\section{Emilia}

Heppie : Happy

Herman

Jan

\section{Lenie}

Lodewijk : Lodewyk

Margriet : 'n tydskrif

Mini : Miemie

Otje : Ottie

Riekje : Riekie

Suzie : Susie

Tante Lena : Tant Lena

Tante Mies : Tant Mien

Tos : Tom

Truus : Truida

\section{LYS C: KLANKNABOOTSENDE NAME}

Boef

Kwark

Tiet : Twiet

Toep 


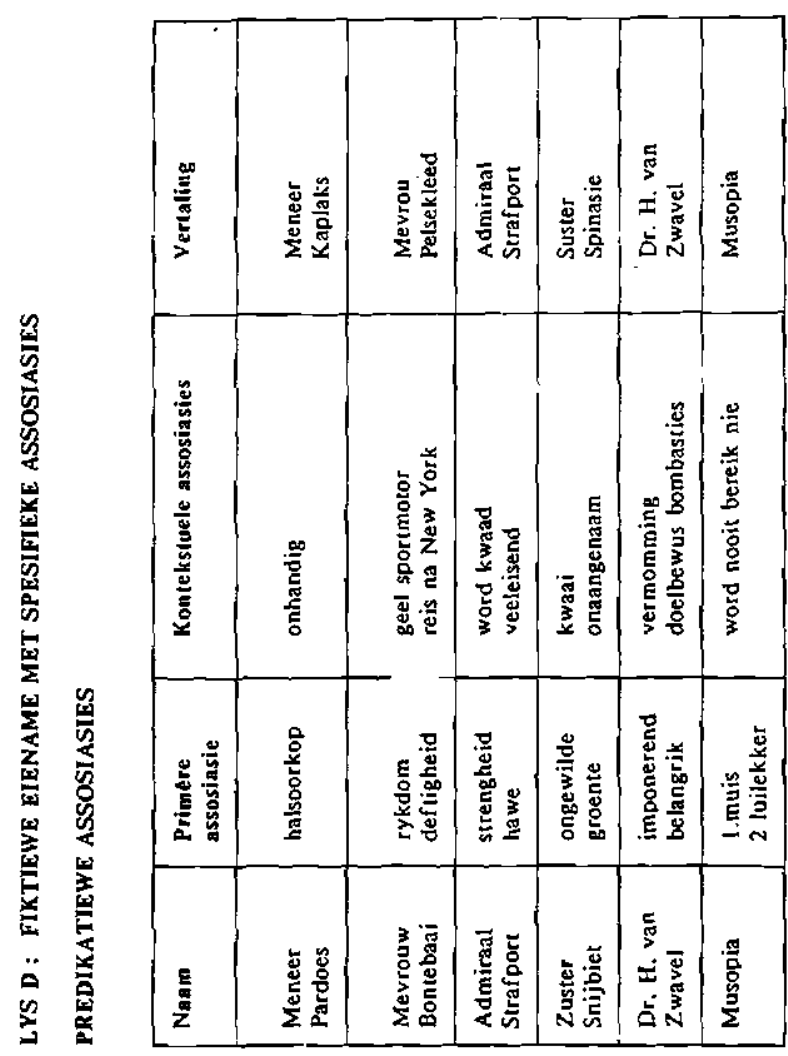


http://spilplus.journals.ac.za/

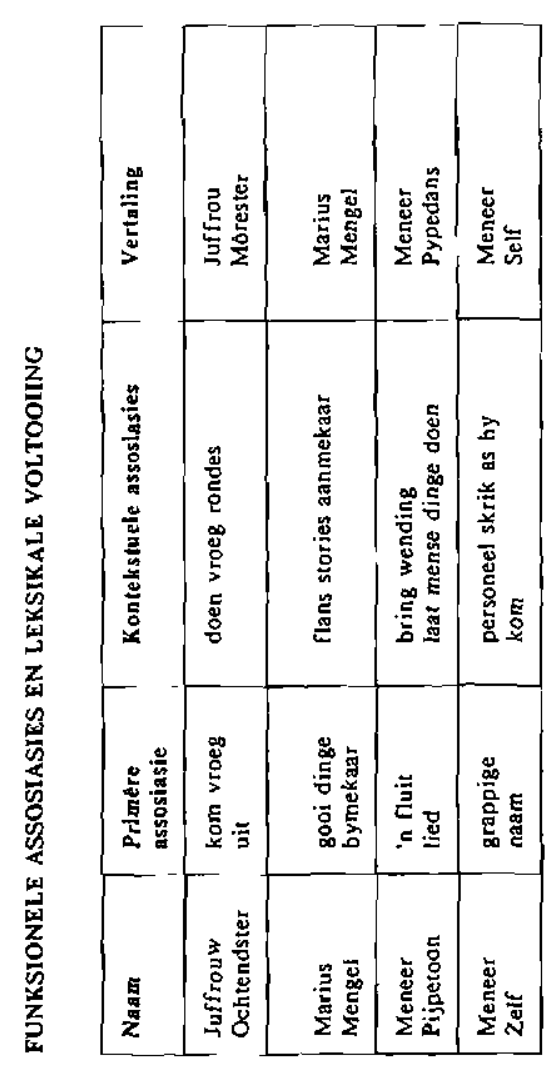


http://spilplus.journals.ac.za/

\section{VOETNOTE}

1 Die werk wat in hierdie referaat vervat is, is gedoen onder leiding van Proff. D.P. Wissing en A.L. Combrink, albei van die P.U. yir C.H.O.

\section{BIBLIOGRAFIE}

BAL, Mieke 1980. De theorie van vertellen en verhalen: inleiding in de narratologie. Muiderberg : Coutinho.

BRINK, A.P. 1987. Vertelkunde: 'n Inleiding tot die lees van verhalende tekste. Pretoria : Academica.

CHOMSKY, N. 1965. Aspects of the theory of syntax. Cambridge, Mass. : M.I.T. Press.

CLARK, H.H. 1970. Word associatin and linguistic theory. (in Lyons, J.J., ed. New horizons in linguistics. Harmondsworth : Penguin : 271-286).

DE SAUSSURE, F. 1966. Kursus in algemene taalkunde. Vertaal deur Alewyn Lee. Pretoria : Van Schaik.

DEESE, J. 1962. On the structure of associative meaning. Psychological Review,69:161-175.

DU PLOOY, Heiltje J.G. 1984. Verhaalteorie in die twintigste eeu: Sintese en toepassing. Potchefstroom. (Proefskrif (D.Litt.) PU vir CHO.)

GEMSER, B. 1924. De beteekenis der persoonsnamen yoor onze kennis van het leven en dinken der oude Babyloniërs en Assyriërs. Wageningen : Veenman.

HAFFTER, P. 1984. Sosiokulturele voorveronderstellings en moontlike oplossings vir die weergawe daarvan in literêre vertalings. Tydskrif vir geesteswetenskappe, 24(1):1731, Maart.

HAWKES, T. 1977. Structuralism and serniotics. London : Methuen.

ISER, W. 1980. Interaction between text and reader. (In Suleiman, Susan and Crosman, Inge (eds.) The reader in the text. New Jersey : Princeton University Press.)

JAUSS, H.R. 1982. Ästhetische Erfahrung und literarische Hermeneutik. Frankfurt/Main : Suhrkamp. 
http://spilplus.journals.ac.za/

259

KRUGER, Hester J. 1988. Naamgewing by die Moganestam: 'n kultuurhistoriese en linguistiese beskrywing. Potchefstroom. (Verhandeling (MA-Afrikatale) - PU vir CHO.)

MORAN, LJ. 1966. Generality of word-association response sets. Psychological Monographs: General and Applied, 80(4):1-25.

NELSON, Maria E. 1991. 'Ze willen grieven eten': Teorie en praktyk van die vertaling van 'n Nederlandse kinderboek. Potchefstroom. (Proefskrif (D.Litt.) P.U. vir C.H.O.)

NEWMARK, P. 1981. Approaches to translation. Oxford : Pergamon Press.

NICOLAISEN, W.H.F. 1976. Are there connotative names? Names, 26(1):41.47, March.

NOTH, M. 1980. Die israelitischen Personennamen im Rahmen der gemeinsemitischen Namengebung. Hildesheim : Georg Olms.

RIMMON-KENAN, S. 1983. Narrative fiction: Contemporary poetics. New York : Methuen.

SMITH, E.C. 1966. The significance of name study. In Blok, C.P., ed. Proceedings of the eighth International Congress of Onomastic Sciences. The Hague : Mouton. p.492-499)

SUCKSMITH, H.P. 1970. The narrative art of Charles Dickens. Oxford : Clarendon Press.

VAN DER MADE-VAN BEKKUM, 1.J. 1973. Nederlandse woordassociatie normen. Amsterdam : Swets \& Zeitlinger. 